\title{
Simultaneidade e fragmentação \\ na ontologia da arte em Kant
}

Simultaneity and fragmentation on Kant's ontology of art

\author{
Mstnd. Irlim Corrêa Lima Júnior \\ dinhoirlim@gmail.com \\ PUC - RIO
}

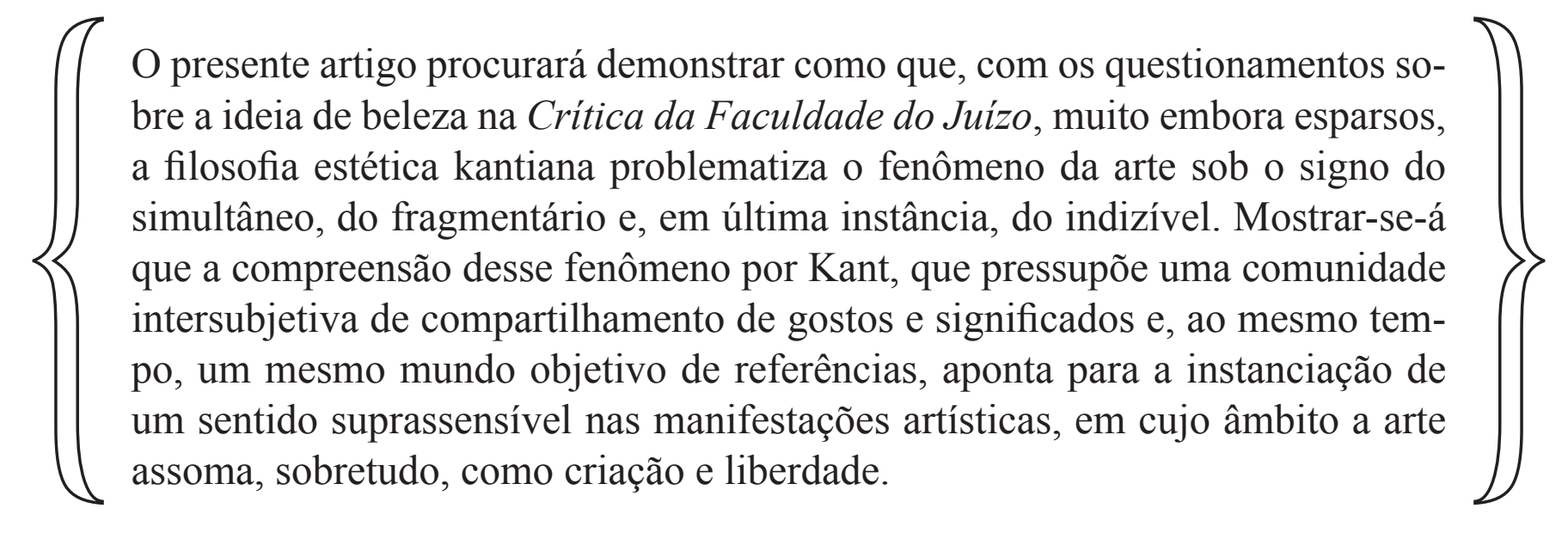

PALAVRAS-ChAVE Kant . Estética . Ontologia . Intersubjetividade . Simultaneidade

The present paper intends to demonstrate how, with the questionings regarding the idea of beauty in the Critique of Judgment, although sparse, Kant's aesthetic philosophy problematizes the phenomenon of art under the sign of the simultaneous, the fragmentary and, ultimately, the unspeakable. It will show that the understanding of this phenomenon by Kant, which presupposes an intersubjective community of sharing of tastes and meanings and, at the same time, a same objective world of references, points to the instantiation of a supersensible meaning in artistic manifestations, within which the art looms, above all, as creation and freedom.

KEY-WORDS Kant. Aesthetic. Ontology. Intersubjetivity. Simultaneity 
Sob o signo do que na filosofia do início do século XX possa ser traduzido como Lebenswelt ${ }^{1}$, o mundo da vida, trama de transcendência extático-vital irredutível às pretensões da razão humana ou quiçá divina de enredá-la em estrutura permanente e suficientemente compreensiva de significações, a metafísica e seu duplo, a filosofia transcendental, por fim ruíram por completo, após longo desgaste das querelas filosóficas no século XIX, pela inviabilidade de fundação legítima de um fundamento inabalável. Se o escolho da coisa-em-si - o que amiúde um dogmatismo tratou como um continente - desde Kant já não mais oferecera segurança em meio ao mar caótico de devir nas intuições na sensibilidade, tampouco as categorias ou os movimentos do espírito puderam oferecer uma embarcação rija e robusta o bastante para singrá-lo. Entre a falta de porto ou leme, naufragou o projeto de alicerçar ou direcionar a compreensão humana da realidade, seja objetiva, seja subjetivamente. E se esse Lebenswelt, para o qual nos atiramos com certa familiaridade, assinalou essa trágica derrocada, foi somente porque nos encobriu com sua máscara viva a dionisíaca vontade de potência (NIETZSCHE, 2011), prenhe do caos e do abismo informe, sobre a qual desde sempre nos encontrávamos em deriva.

O que sucedera à ontologia, sucedeu à estética. Embora com um percurso de autonomia muito mais recente, o paradigma sobre o qual se erigiu a estética em vista de uma compreensão fundante e essencial da arte não encontrou fim diferente. A beleza, o belo, como fundamento identitário e fundação necessária para o fenômeno da arte e das obras de arte foi não apenas rejeitada, criticada, ignorada em sua ideia pelas diversas correntes artísticas e pelos artistas desde o fim do século XIX até os dias de hoje, como também sua pretensão por responder pela identidade e essência da arte foi completamente repudiada. Para além disso, toda e qualquer identidade, essência, fundamento ou fundação já não mais se nos antolham como possíveis conceitos para compreensão do fenômeno artístico. Aliás, também a arte se encontra lançada na urdidura caótica e complexa desse mundo da vida, cuja fragmentariedade e ao mesmo tempo inextrincáveis interconexões não permitem divisar em hipótese alguma compreensões, racionalizações, entendimentos, ou sequer genealogias unívocas. A despeito da proliferação do fenômeno artístico em suas multifacetadas performances e diferentes manifestações cuja diferença ousa beirar o infinito,

1 Em sentido estrito, esse conceito remete a Husserl e assim o explicita Urbano Zilles na introdução de sua tradução de Husserl: "O Lebenswelt é o âmbito de nossas originárias "formações de sentido", do qual nascem as ciências. Para Husserl, o mundo da vida é um a priori dado com a subjetividade transcendental." (HUSSERL, 2002, p. 32) Contudo, lançando mão aqui desse conceito fora do contexto de uma filosofia intimamente vinculada à esfera da subjetividade, queremos apenas indicar que a vida mesma em sua ampla conjuntura é o a priori de todo fazer e pensar no qual emergimos e somos lançados. 
semelha-nos que afinal a arte como o duplo da vida, deste mundo da vida - não da efetividade aí com que lidamos cotidianamente, mas da crueldade pujante de onde a vida emerge, no dizer de Artaud (2006) - se tornou a possibilidade de compreensão incompreensiva (ou de incompreensão compreensiva) para a carestia de origem e de sentido para a arte.

O declínio da unidade harmoniosa do belo e de seus subsequentes imperativos ontológicos franqueou passagem aos arrojos ensaísticos de se pensar a arte como embriaguez da própria vida consigo mesma, replicação da crueldade originária como forma de retorno a sua originariedade, cisão e memória entre traço e contínuos sentidos de falta e incompletude, entre tantas outras concepções que já não mais se concebem senão como narrativas que permeiam a impossibilidade da configurar uma história universal. São realmente ensaios do constante exercício de iterar o indizível.

Neste sentido, pode sempre parecer que se debruçar sobre as concepções estéticas tradicionais, que se tornaram o topos clássico da reflexão sobre a arte, não seja mais que um manejo de uma prática erudita ou, quando muito, uma releitura para atualização hermenêutica da tradição no intento de redirecionar certos problemas e questionamentos, mesmo que se reconheça sua indigência para dar conta da conjuntura total da atualidade, muito embora amiúde apresentem questões parciais relevantes.

Contudo, é possível que justamente onde se encontrou tanta harmonia, unidade e totaliaridade, enquanto pretensas propriedades eidéticas do conceito metafísico de beleza, o qual lançou rédeas sobre a arte por séculos e séculos, aí possamos também vislumbrar uma topografia bem distante de ser plana e homogênea, não obstante em seu contexto histórico se apresentasse discursivamente assim. Talvez releituras mais heterodoxas e nem um pouco dogmáticas a respeito de estética e de filosofia da arte logrem demonstrar já Platão e Aristóteles a insuficiência de suas reflexões como esboços, com a fragmentariedade dos seus planos e a - talvez consciente - indigência dos seus conceitos. Desta forma, poder-se-ia conferir de fato atualidade às obras que se tornaram clássicas, como narrativas - que tanto na sua sincronia própria quanto na nossa sincronicidade de exposição e extremo da fragmentariedade - possíveis para a insuficiência diacrônica que nos impossibilita uma metalinguagem para a imensa teia na qual estamos emaranhados. Em suma, tratar-se-ia de revertê-las do antiquário da vontade de verdade, no qual soeram permanecer imóveis, cristalizadas e empoeiradas, em vontade de potência, reconduzindo-as ao problema transtemporal do fenômeno artístico de onde partem, como também elas partiram, todos os esboços e ensaios que reflexivamente o tematizam. 
Em vista disso, é sempre necessário iterar, reproblematizar, desconstruir, desfigurar, reconfigurar, ressignificar... os conceitos, o texto, o contexto e o mundo de sentidos em que surgiram. Com este intento, é preciso mergulhar no mar de fragmentação ininterrupta que tempestua na Crítica da Faculdade do Juízo e na insuficiência de seus conceitos e de seus pressupostos diante dos problemas que apresenta. Não para o desmérito dessa monumental obra, mas, como dissemos, muito pelo contrário, justamente para recupermos a permanente atualidade do seu sentido narrativo.

Se muito fizeram filósofos posteriores, a crítica e seus comentadores com o fito de desfragmentar essa fragmentação originária para aperfeiçoá-la em vista da unicidade de seu desígnio e escopo, aqui nada será feito nesse sentido. Mas tampouco atentaremos aos textos estritamente. Não há literalidade, como não há tendência à unidade de sentido. Se tomamos a $3{ }^{a}$ Crítica como narrativa, então o que aqui intentamos é uma narrativa de uma narrativa - e não a narratividade (ou uma sinopse) dessa narrativa. Tampouco será descritiva, posto que, enquanto narrativa, reficcionaliza seu sentido. Será descontínua e parcial, porém tecendo questionamentos cujos liames se enredam com pontos nodais a partir dos quais quem sabe seja possível visualizar um horizonte postulativo para se pensar uma topografia acidentada - mas possível - para a sua totalidade interdita.

\section{Do incondicionado à intersubjetividade}

O sentido do realismo empírico kantiano de oferecer bases gnoseológicas rigorosas e assegurá-las para a produção e evolução do conhecimento das ciências se alicerçou na fundamentação transcendental do seu idealismo, o qual, no entanto, sempre esbarrou numa problemática "infundamentação teórica de última instância"2 e transcendente de sua transcendentalidade. Esta infundamentação teórica teve de ser assumida como fundamento postulativo-racional último em relação a todos os fenômenos, na medida em que estes últimos se apresentam como conhecimentos sintéticos condicionados, dada a sua própria natureza objetiva, o que implica de antemão delimitações ontológicas próprias pelo fato de se tratarem de objetos. Enquanto condicionados, pois, pressupõem

2 Trata-se, em resumo, do problema de assumir como postulado teórico necessário da razão o incondicionado absoluto como princípio supremo para todo e qualquer condicionado, embora não seja, por natureza, esse princípio demonstrável. Nas páginas seguintes fazemos demonstração desse problema. Cf. HEIDEGGER, 2009, 265-316. 
por princípio condições. Como estrutura da subjetividade transcendental, que responde pela própria objetividade dos objetos e, portanto, pela sua condição de possibilidade formal, as formas puras da intuição (espaço e tempo) e os conceitos puros do entendimento, estabelecidos por Kant na Crítica da Razão Pura, se apresentam como os pilares do aparecer fenomenal. Contudo, ainda não o solo onde tais se fixam. É próprio da razão ser impelida a procurar os princípios que regem a produção de conhecimento e os limites de sua própria capacidade de pensar e conceber, enquanto faculdade que, extravasando os limites do condicionado, não se detém até encontrar o que se mostraria como o incondicionado, isto é, como condição última de todo condicionamento. Com efeito, “o princípio próprio da razão em geral é (...) encontrar, para o conhecimento condicionado do entendimento, o incondicionado pelo qual se the completa a unidade.” (KANT, CRP, A307/B364, 2001, p. 329-330) Tais princípios apontam para “(...) a orientação a uma certa unidade, de que o entendimento não possui qualquer conceito e que aspira a reunir, num todo absoluto, todos os atos do entendimento com respeito a cada objeto." (ibidem, A326-7/B383, p. 342-343) Sem dúvida, essa unidade absoluta não é nada de utilizável para a experiência, pois nenhum conhecimento empírico é incondicionado. Seu uso é apenas transcendente (ibidem, A327/B383, p. 343), ao qual, não sendo dado nenhum objeto da intuição correspondente, cabe um papel especulativo, porém, jamais arbitrário. Pelo contrário, sua especulação é necessária à própria razão, pelo próprio fato da pressuposição do incondicionado ao condicionado como seu fundamento e princípio regulatório. Ao que responde por essa unidade absoluta é chamado de ideia transcendental ou conceito puro da razão.

\footnotetext{
Os conceitos puros da razão, que agora estamos a considerar, são pois ideias transcendentais. São conceitos da razão pura, porque consideram todo o conhecimento de experiência determinado por uma totalidade absoluta de condições. Não são forjados arbitrariamente, são dados pela própria natureza da razão, pelo que se relacionam, necessariamente, com o uso total do entendimento. (ibidem, A327/B384, p. 343)
}

Em outra passagem, diz Kant que as ideias transcendentais correspondem 
(...) à totalidade (universitas) das condições. Assim, o conceito transcendental da razão é apenas o conceito da totalidade das condições relativamente a um condicionado dado. Como, porém, só o incondicionado possibilita a totalidade das condições e, reciprocamente, a totalidade das condições é sempre em si mesma incondicionada, um conceito puro da razão pode ser definido, em geral, como o conceito do incondicionado, na medida em que contém um fundamento da síntese do condicionado. (ibidem, A322/B379, p. 340)

Por essa passagem, fica claro como que, segundo Kant, a totalidade das condições supõe necessariamente como postulado teórico - não empírico, porquanto impossível de ser conhecido, ou seja, figurado em uma intuição - um fundamento que realize a síntese totalitária dessas mesmas condições como incondicionado. Como unidade suprassensível que é assumida como fundamento teórico para os fenômenos, as ideias se nos apresentam como a "unidade de razão nos fenômenos" (ibidem, A326/B383, p. 342). Elas respondem, mesmo como postulado, pela unificação do múltiplo fenomênico sob uma mesma trama, cujos entrelaçamentos figuram como fenomenalizações atuais ou possíveis, mas cuja tessitura fica sempre, por natureza, encoberta nos fenômenos.

As ideias, portanto, foram tomadas como axiomas eidéticos e absolutos da razão, sem as quais não é possível ser racional algum ser capaz de pensar na destinação inalcançável, mas totalitária, de sentido de tudo aquilo com que suas faculdades cognitivas se relacionam.

Tais sentidos são apenas perfilados especulativamente, sem que sua totalidade possa ser na verdade pensada totalitariamente e muito menos conhecida. “Assim, poder-se-ia dizer que a totalidade absoluta dos fenômenos é apenas um ideia, pois como não podemos nunca realizar numa imagem algo semelhante, permanece um problema sem solução.” (ibidem, A328/B385, p. 343)

De fato, à barreira espaço-temporal da estética transcendental soma-se ainda a da faculdade do entendimento que somente produz conceitos - o que para Kant significa o mesmo que conhecimento - a partir de suas categorias transcendentais que unificam o múltiplo das intuições recolhidas na sensibilidade, zona fronteriça que demarca o que nos é possível travar conhecimento e para além da qual isto não nos é possível. 
A abrangência dessa zona diz respeito não apenas a multiplicidade dos fenômenos, mas também a posição das partes entre si, determinando-as a priori (ibidem, A832/B860, p. 669), o que ensejaria aventar a possibilidade de uma arquitetura transcendental, ainda que sob a forma de um esboço, relativo à totalidade fenomênica sob a condição de uma unidade cuja identidade possibilite e estruture toda aparição.

Contudo, dentre esse complexo estrutural uma triplicidade de conceitos forçosamente se estabelece como uma íntima conexão entre conceitos basilares para a fundação desse edifício de unificação de totalidade das condições.

Ora, tomada na sua universalidade, toda a relação que as nossas representações podem possuir consiste: 1. na relação com o sujeito; 2. na relação com os objetos, quer sejam fenômenos, quer objetos do pensamento em geral; 3. com todas as coisas em geral. (...) Por conseguinte, todas as ideias transcendentais podem reduzir-se a três classes das quais a primeira contém a unidade absoluta (incondicionada) do sujeito pensante, a segun$d a$, a unidade absoluta da série das condições dos fenômenos e a terceira, a unidade absoluta da condição de todos os objetos do pensamento em geral. (ibidem, A333-4/B390-1, p. 347)

A saber, pois, respectivamente, alma, como a totalidade do incondicionado dos estados psíquicos, mundo, como a totalidade do incondicionado dos fenômenos em fluxo, e Deus, como a totalidade absoluta do incondicionado, são ideias postuladas pela faculdade da razão como conceitos incondicionais especulativos para pensar para além dos seus limites, sem vias, contudo, de acesso que lhes permita descortinar conhecimento efetivo relativo a fenômeno algum. A razão pura, deste modo, é a faculdade dos princípios absolutos da síntese a priori (HEIDEGGER, 2009, p. 305), que "antes" mesmo das sínteses condicionadas do entendimento efetua a condição absoluta de possibilidade que permite todas as sínteses "ulteriores", ou, melhor dizendo, subsequentes.

Deste modo, as ideias kantianas distam absolutamente das platônicas. Para Platão, por mais que a linguagem limitasse o acesso de contemplação das ideias devido à sua natureza limitadora e mimética, havia uma confiança de que uma contínua e minuciosa dialética seria capaz de em algum momento de insight 
descerrar o véu dos fenômenos condicionados ao devir e intuir o suprassensível incondicionado da eternidade. Assim, a ideia platônica é o apreensível pela retidão do olhar metafísico do intelecto, como a definição identitária e essência fundante que reúne a multiplicidade dos fenômenos em si e a partir da qual tais são produzidos por participação ou reproduzidos em segunda mão por mímesis. As ideias em Platão consistem, pois, na configuração essencial dos objetos, sob cuja identidade são o que são permanecendo eles mesmos. ${ }^{3}$

As ideias kantianas, contudo, carecem por completo desse caráter de objetidade. Com efeito, não podem ser definidas, caracterizadas, contempladas... Como dissemos, não lhes há propriamente objeto algum, pois nenhum fenômeno enquanto tal a comunica. Não há possibilidade alguma de superação (e nem de suprassunção) dialética aos píncaros do conhecimento, porquanto estejam fadadas aos domínios analíticos de uma razão que encontra nelas a finitude daquilo que lhe é pensável, por destinação ontológica a um desígnio que lhe é ignoto, mas infalível, de estarem-lhe cerradas as portas para a transcendência. As ideias são apontamentos presentes na razão humana de sua destinação suprassensível e de uma significação absoluta que a admoesta para além de tudo quanto pode conhecer. São o para além dos objetos de seu conhecimento, para além dos estados psíquicos do sujeito; radicalmente, são o para além da objetividade e subjetividade, embora em referência a elas de alguma forma.

Mundo, alma e Deus constituem na Crítica da Razão Pura o fundamento sem chão numênico sobre o qual nenhum conhecimento se baseava, mas também sem o qual nenhum direciomento de compreensão global da fenomenalidade lobrigasse ser possível, não importando a vertigem diante de tamanho abismo.

O que a princípio parece ser um excurso do tema a que nos propomos, justifica-se, de começo, pelo fato da Crítica da Faculdade do Juízo inserir em seus desdobramentos reflexivos a mesma problemática das ideias para a compreensão do fenômeno artístico como o belo e sua relação com a pretensão de universalidade do juízo de gosto. Nessa obra, recupera-se o conceito de ideia assim:

Ideias, na significação mais geral, são representações referidas a um objeto de acordo com um certo princípio (subjetivo ou objetivo), na medida contudo em que elas jamais podem tornar-se conhecimento desse objeto. (KANT, 2012, p. 203)

3 "As ideias são, para ele (Platão), arquétipos das próprias coisas e não apenas chaves de experiências possíveis, como as categorias.” (KANT, CRP, A313/B370, 2001, p. 335). 
Objeto especificamente nessa passagem não deve ser de modo algum confundido com nada de objetivo, representativo, nada que se possa figurar diante de um sujeito. Objeto aqui diz respeito à natureza temática da própria ideia. Essa natureza, que pode ser assunto dos voos especulativos da razão, sem, contudo, vir a ser-lhe conhecida, é adotada como fundamento pressuposto, postulativo, mas necessário, ao qual se deve supor que se subordina todo o condicionado. As condições, pois, da estrutura transcendental da subjetividade são concebidas como campo das instanciações possíveis de produção de sentido e formalidade para a matéria bruta que lhe é advinda, cuja origem incognoscível é pressuposta como uma totalidade incondicionada que não pode ser sequer entrevista sob condição teórica alguma, mas sobre a qual a razão se apoia como um princípio.

Na $3^{a}$ Crítica, com efeito, isso se relaciona com o belo e com o juízo de gosto. O belo (das Schöne) é lá definido como "a forma da conformidade a fins de um objeto, na medida em que é percebida sem representações de um fim" (ibidem, p. 79), enquanto que gosto (Geschmack) como "a faculdade do ajuizamento de um objeto ou de um modo de representação mediante uma complacência ou descomplacência independente de todo interesse. $\mathrm{O}$ objeto de uma tal complacência é chama-se belo."4 (ibidem, p. 47) Ambos, pois, se correlacionam de forma inextrincável, sendo um o sujeito (o gosto) e o outro o objeto ${ }^{5}$ (o belo). Ambos se complementam e perfazem uma mesma realidade ideal que se apresenta sob dupla face. Daí, pois, necessariamente o juízo de gosto ser um juízo acerca do belo. Tal complacência despertada no sujeito se apresenta de forma desinteressada, o que com isto é forçoso entender tanto a ausência de utilidade (característica do que é considerado como bom, em vista de sua utilidade objetiva) quanto irredutibilidade aos prazeres da sensação (deleite próprio da amenidade, para o qual até mesmo os animais se mostram aptos).

O juízo do belo é, antes de tudo, um juízo contemplativo-reflexionante a respeito não de uma propriedade intrínseca ao objeto artístico, mas a partir do sentimento estético que é despertado na subjetividade diante da obra de arte. Com efeito, “(...) se tem de atribuir ao juízo de gosto, com a consciência da separação nele de todo interesse, uma reivindicação de validade para qualquer um, sem universalidade fundada sobre objetos, isto é, uma universalidade subjetiva tem de estar ligada a esse juízo.” (ibidem, p. 48) Posto que fundado em um sentimento, constituindo-se, deste modo, como subjetivo, esse juízo não pode

4Só neste ponto nodal haveria muito que deslindar, porém, tendo em vista avançarmos pelo fio condutor do nosso questionamento, não será conveniente fazê-lo por ora.

5 No sentido supramencionado de objeto. 
encontrar sua adveniência da objetividade do mundo fenomênico e tampouco pode ser capaz de traduzir-se por conceitos. Antes, suas proposições judicativas entremeiam-se na zona lúdica e crepuscular entre a faculdade da imaginação e do entendimento, sendo estimuladas continuamente no jogo sem fim e sem finalidade de, emulando-se uma faculdade com a outra, produção criativa de reflexão estética. (ibidem, p. 37-38)

Os juízos estéticos fundam-se, portanto, na subjetividade. "O juízo de gosto não é, pois, nenhum juízo de conhecimento; por conseguinte, não é lógico e sim estético, pelo qual se entende aquilo cujo fundamento de determinação não pode ser senão subjetivo." (ibidem, p. 38) Mas diante disso abre-se um problema de magnitude colossal: como é possível pensar em sua comunicabilidade, em seu compartilhamento e em sua pretensão de universalidade, se, afinal, sua fundação se encontra arraigada num sentimento subjetivo sem liames necessários com propriedades objetivas? É verdade que Kant procurará responder a isso, pelo menos em parte, através das condições formais pelas quais esses juízos são produzidos e emitidos.

Ele (quem julga) fará, pois, do belo como se a beleza fosse uma qualidade do objeto e o juízo fosse lógico (constituindo através de conceitos do objeto um conhecimento do mesmo), conquanto ele seja somente estético e contenha simplesmente uma referência da representação do objeto ao sujeito; porque ele possui semelhança com o lógico, pode-se pressupor a sua validade para qualquer um. (ibidem, p. 48)

Nada obstante não existirem regras que forcem o juízo estético a reconhecer algo como belo, o que inviabiliza de antemão a imputação de uma tendência de unanimidade que os críticos e os clássicos tanto buscaram, há, contudo, na simples forma a priori de conformidade a fins na representação uma possibilidade de fundamentação que determine não regras, mas condições de possibilidade pelas quais são determinados os juízos de gosto. É verdade que o “(...) juízo de gosto não tem por fundamento senão a forma da conformidade a fins de um objeto." (ibidem, p. 60) Todavia, pensa-se aqui no âmbito de uma validação formal, mas não de ser uma fundamentação propriamente ontológica. Essa determinação a priori não se deixa reduzir a conceitos, nem se traduzir por juízos - e nem sequer por condições formais análogas ao do conhecimento objetivo. 
O juízo de gosto que é produzido pelo despertar de um sentimento diante do prazer estético, juízo, pois, que reflexiona sobre um conteúdo concreto, de um particular de uma obra de arte, então, encontra em uma estrutura transcendental de ajuizamento, que precede ontologicamente os juízos de gosto singulares, a possibilidade de embasamento de universalidade que lhe é minimamente requerida para que sejam compartilhados e compreendidos pelos mais diferentes sujeitos humanos. Só porque todos os homens possuem em comum uma mesma estrutura de subjetividade é que são capazes de conferir uma mesma formalidade comunicável, a despeito da diversidade e pluralidade de significações, sentimentos e conteúdos irredutíveis a parâmetros, categorias ou a consensos. A subjetividade transcendental, antes, é que deve ser considerada como o correlato fundacional necessário e condicional do ajuizamento como estrutura transcendental da experiência estética, como o próprio Kant o reconhece:

Para ter direito a reivindicar um assentimento universal em um juízo da faculdade do juízo estético, baseado simplesmente sobre fundamentos subjetivos, é suficiente que se conceda (...) que em todos os homens as condições subjetivas desta faculdade sejam idênticas com respeito à relação das faculdades de conhecimento aí postas em atividade em vista de um conhecimento geral; o que tem de ser verdadeiro, pois do contrário os homens não poderiam comunicar entre si suas representações e mesmo o conhecimento (...). (ibidem, p.143)

Não haveria comunicação entre os homens sem que as condições subjetivas funcionassem como uma mesma base de inteligibilidade universal, válida para todos. De fato, é isto que requer mesmo sua universalidade. Mas, para além disso, não podemos nos perguntar se não apenas uma comunicação não seria possível, a nível de entendimento, mas, principalmente, que não seria possível realidade de comunicação alguma? Não haveria, nesse caso, um entrave ontológico muito mais do que comunicacional? Pois aqui a comunicação pressupõe uma realidade de comunicabilidade entre os diversos sujeitos. Mas sob o pressuposto de que as condições transcendentais sejam as mesmas. Essa é sua condição, porém ainda não suficientemente fundamentada, isto é, sem tocar ainda qualquer coisa de incondicionado. 
Ademais, outra questão se impõe aqui, mas que veremos adiante como se entrecruza com essa. Pois, ainda que esta formalidade universal, que responde por certa identidade, transmita-nos uma frequência em comum pela qual todos os juízos flexionam sua reflexividade, fica-nos ainda a pergunta do que responde pela sua infinita produção diferenciada, uma vez que essa identidade é por demais formal e abstrata para retirar de si algo de determinado. A materialidade dos juízos estéticos e do objeto artístico é heterogênea em relação a essa formalidade identitária? Há origens diversas para ambas? O apelo ao caráter lúdico da relação entre entendimento e imaginação são igualmente ineficazes em vista disso, pois igualmente tão-só apresentam condições formais não menos insuficientes, nada obstante enriquecedoras, porque supõe também serem faculdades formais idênticas para todos. Afinal, se as condições formais são as mesmas para todos e se todos podem se colocar diante de uma mesma obra, com as condições espaço-temporais e categoriais fenomênicas igualmente objetivas, de onde pode então emergir tanta diversidade de sentimentos, gostos, opiniões, reflexões, etc.?

Nesse ponto caberia quiçá aventar para as críticas de Husserl (2001) acerca de concepções de subjetividade como a de Kant, formalmente cindida e abstraídas do fluxo de vivências que lhe é um correlato necessário para a sua própria configuração transcendental e produção-doação de sentido, como um caminho para se pensar a diversidade de reflexões estéticas a partir da diversidade ontológica do fluxo de vivências egológicas, irredutível à alteridade, posto que próprio de cada um. Mas isso então subordinaria em nexo causal ou motivacional a Ursprung, sua fundação originária, da imotivação a priori estética a uma outra ontologia regional, a partir da qual não se pode derivar a priori seu próprio território gênese. Igualmente, à sensação sensorial (Sinnesempfindung) (ibidem, p.145) como o real da percepção objetiva seria preciso conceber sua relação com o fenômeno estético e sua possível estetização mediante a imaginação. Mas isso, colocado à luz do problema de uma comunidade de sujeitos múltiplos partilhando suas sensações, sentimentos e reflexões por meio de juízos, não careceria de um mundo da vida transcendental (Lebenswelt), que reunisse por uma mesma vitalidade transcendental pertinente a todos os sujeitos suas vivências estéticas como possibilidades de estetizações no âmbito de cada subjetividade, sem, porém, que esse múltiplo seja passível de ser traduzido por uma eidética, dado seu caráter objetivo? Em relação à multiplicidade das vivências estéticas não se faz mister um mundo da vida de intersubjetividade transcendental como seu fundamento e condição de possibilidade?

$\mathrm{Na}$ permanência da indissolubilidade dessa questão é que assoma na $3^{a}$ Crítica a necessidade da postulação de ideia estética da beleza como princípio global fundante da obra de arte e da diversidade judicativa. 


\title{
Ideia estética e sentido comum como fundamentos da intersubjetividade estética
}

A universalidade estética com seu quantum de subjetivo, também chamada de validade comum (Gemeingültgkeit), não se refere à validade com referência a uma representação ou propriedade alguma desse objeto fenomênico, mas sim ao sentimento subjetivo que está em jogo.

\begin{abstract}
Ora, aqui se deve notar, antes de tudo, que uma universalidade que não se baseia em conceitos de objetos (ainda que somente empíricos) não é absolutamente lógica, mas estética, isto é, não contém nenhuma quantidade objetiva do juízo, mas somente uma subjetiva, para a qual também utilizo a expressão validade comum (Gemeingültgkeit), a qual designa a validade não da referência de uma representação à faculdade do conhecimento, mas ao sentimento de prazer e desprazer para cada sujeito. (KANT, 2012, p. 51)
\end{abstract}

A referência imediata da validade comum são os sentimentos estéticos despertados nos sujeitos mediante o objeto artístico - o qual, porém, como objeto da complacência não nos é figurado em si, mas segundo o constructo imagético que espontaneamente nos é dado pela faculdade da imaginação, já que esta possui um ativo papel essencial na fenomenalização da arte. Com a validade comum, cria-se uma vinculação entre compossíveis validações estéticas de julgamentos que, sincrônicas ou não, comunicam uma mesma identidade. Esta responde pela forma de conformidade a fins. Essa finalidade não é de modo algum extrínseca ao objeto da complacência, antes, reside nele mesmo. Ao comentar a respeito da estética kantiana, escreve Hegel: “(...) o belo deve ser de natureza finalista, mas apenas de uma finalidade que reside no próprio objeto, independentemente da representação de um fim qualquer." (1996, p.78) É verdade, pois, que as finalidades variarão tanto quanto os objetos artísticos. Porém, a todos eles é pertinente a forma de conformidade como condição de possibilidade da experiência artística e de sua comunicabilidade. E justamente essa condição transcendental aponta-nos para a sua identidade mais interna.

Na medida em que estabelece a possibilidade da comunicação, estabelece também uma comunidade. Por esta comunidade vinculativa entremeia-se uma comunicação estética de compartilhamento de sentidos. 
(...) humanidade (Humanität) significa de um lado o universal sentimento de participação e, de outro, a faculdade de poder comunicar-se íntima e universalmente; estas propriedades coligadas constituem a sociabilidade conveniente à humanidade (Menschheit), pela qual ela se distingue da limitação animal. (KANT, 2012, p. 219)

A Menschheit, como forma de sociabilidade humana, à diferença dos animais, não possui limites, destinando ao infinito e ao suprassensível as relações sociais humanas, posto que fundadas no âmbito da liberdade em face dos condicionamentos do mundo sensível. É verdade que essa sociabilidade não é o acúmulo de partes diversas entre si de modo a se tornarem um todo pelo qual ela mesma se dê. Em outras palavras, a Menschheit não é uma sociedade. Ela implica, enquanto conjunção entre sentimento de participação e faculdade de poder de comunicação, que cada sujeito já a possua como sua condição estrutural. Já na singularidade de uma subjetividade ela se faz presente, não substancialmente, mas transcendentalmente.

No entanto, não decorre disso que ontologicamente o singular por princípio já se encontra correlacionado com uma comunidade? Faz algum sentido que o sentimento subjetivo de participação seja uma possibilidade antes mesmo que a possibilidade da participação comunitária se apresente? É evidente que aqui o problema não é, de maneira alguma, cronológico. E sim transcendental, o que não diz respeito a efetividades ou a nexos causais de índole ou orientação natural. Igualmente se pode pensar a respeito da faculdade da comunicação: que sentido haveria a possibilidade de um sujeito comunicar-se sem que a comunicação entre subjetividades não fosse uma possibilidade? A relação aqui, entre esses dois âmbitos de possibilitações, não pode ser interpretada como uma relação de subordinação, mas de coordenação. Não é o todo que funda a parte, nem o contrário. Comunicacionalidade intersubjetiva e comunicabilidade subjetiva apresentam-se como dimensões congêneres de um mesmo jogo.

A comunicação se estabelece pela simultaneidade dessa dupla de poderes, que entre si jogam um mesmo jogo. Kant, em ocasião completamente alheia ao que pretendemos, define poder (Macht) como a "faculdade que se sobrepõe a grandes obstáculos. Esta chama-se força (Gewalt) quando se sobrepõe também à resistência daquilo que possui ele próprio poder." (ibidem, p. 108) Essa cita- 
ção, embora espúria, pois nela Kant trata diretamente da natureza do sublime nos enseja aqui a pensarmos a natureza do poder como meio de refletirmos mais profundamente sobre a natureza desse jogo.

A superação a grandes obstáculos é uma característica da razão pura, na medida em que, se elevando acima de todo o condicionado, procura na síntese das condições o incondicionado, tal qual demonstramos no contexto da Crítica da Razão Pura. Como faculdade dos princípios absolutos da síntese a priori, ela se vê necessariamente impulsionada a pensar nas ideias como o absoluto, no qual tudo o que é inconciliável é reconciliado sob o postulado de uma síntese, que abarque todos os tempos em que o condicionado possa figurar.

Em que isso, porém, nos auxilia a pensar a respeito da comunicação transcendental intersubjetiva? Em parte porque também ela é uma necessidade ontológica enquanto pressuposto para o fenômeno da universalidade do juízo estético e da fenomenalização do objeto artístico. Sua coligação entre elementos diversos no âmbito subjetivo (sentimento estético de participação e poder de comunicação) e no âmbito intersubjetivo (possibilitação intercomunicacional e potencialidade de comunicação) desde já sugere sua natureza sintética. Essa natureza confere ao jogo da comunicação uma propriedade similar ao jogo da imaginação e entendimento, isto é, de ser um jogo sem fim. A comunicação transcendental, com efeito, poderia ser pensada como um eterno jogo sem fim, cuja intrínseca finalidade se mostraria como nada além da fenomenalização de infinitas possibilidades estéticas, tanto de obras de arte como de crítica, que é a própria identidade dessa comunicação. Neste sentido, sua realidade se mostraria como o idêntico de sua atividade. Este jogo se fundaria sobre uma síntese ideal de uma reconciliação do múltiplo inconciliável. É claro que, com isso, o movimento de reconciliação assoma como uma suprassunção abstrata, mas de modo algum arbitrária. No seu poderio, sua necessidade advém da força mesma que lhe opõe resistência, mas que, no fundo, não escapa a seu poder. A resistência é sempre a condição da multiplicidade, da vitalidade, da experiência de se posicionarem obstinadamente como irredutíveis a serem sobrepostas a uma unidade. A singularidade é o grande obstáculo da síntese. O caráter abstrato da síntese, entretanto, não perde sua força diante disso, pelo contrário, é aí mesmo que mostra sua força e sua capacidade de sobreposição. Porque é justamente pelo seu movimento abstrativo de sobreposição da singularidade que o singular é em toda parte e em qualquer tempo assaltado de sua singularidade para assomar como a manifestação de uma identidade, por mais tênue que essa seja.

6 Mas que se justificará melhor nas páginas seguintes, quando nos voltarmos à pergunta pelo sublime e pela sua ligação com os problemas que abordamos. 
O fenômeno artístico abre, então, a espacialidade e a temporalidade do mundo das representações para uma outra dimensão: a adveniência de sínteses ativas de produção de imaginação e de reflexividade. Em grande parte isto já fora delineado na $1^{a}$ Crítica, em relação ao esquematismo e as possibilidades de produção de juízos sintéticos a priori. Mas a novidade da Crítica da Faculdade do Juízo não reside meramente na transposição desse problema para as questões da arte, tampouco na inversão de relação entre faculdade determinante e determinada. A grande inovação aqui é pensar nas questões que tangem a subjetividade para além do sujeito, enveredando a questão para a problemática da intersubjetividade.

A abertura para essa outra dimensão é algo sobre o que Kant somente esboça esparsa e fragmentariamente ensaios para sua problematização, o que, porém, a filosofia do período romântico irá levar às últimas (e extremistas) consequências. Embora isso seja razoavelmente compreensível devido ao escopo de suas obras, de caráter gnosiológico $\left(1^{a}\right.$ Crítica $)$, imperativo-prático $\left(2^{a}\right.$ Crítica $)$ ou judicativo-reflexionante ( $3^{a}$ Crítica), só para citar as principais, o fato é que sua ontologia demasiado fragmentada deixou buracos abertos, criando ingentes dificuldades para sua compreensão ontologicamente fundada de forma absolutamente orgânica e coerente.

Todavia, talvez não seja por acaso que somente a $3^{\circ}$ Crítica proponha o problema e a necessidade de falar de uma comunidade intersubjetiva. É verdade que isso não fora menos necessário em suas obras anteriores, tanto é que na $3^{\circ}$ Crítica figurará um conceito que atenderá à premência de se falar a respeito de um solo fenomenal-objetivo de referência comum a todos os sujeitos objetivamente sob o nome de entendimento comum (senso comum ou também sensus communis logicus), de validade universal e conceitual para todos os sujeitos. A raiz desse problema, no entanto, é tão abissal quanto talvez sua correlativa resposta: a ideia e a fulguração enigmática de seu compartilhamento instancial entre os diversos sujeitos.

E se isso ficou sem resposta como fundação de um mundo objetivo de refência para a intersubjetividade, foi apresentado por Kant similarmente para o problema do fenômeno artístico e da universalidade dos juízos de gosto a noção de sentido comum (chamado também por ele de sensus communis aestheticus). "Pode-se designar o gosto como sensus communis aestheticus e o entendimento comum humano como sensus communis logicus." (ibidem, p. 150) Este sentido comum, com efeito, é o pressuposto necessário a fim de que haja a possibilidade de se conceber pela razão uma ideia que permita a comunicação e a universalidade dos juízos, apesar de lhes faltarem regras objetivas e 
de serem produzidos sob o impulso estético de um sentimento subjetivo. Não é um princípio que diga respeito a conceitos, como o entendimento comum, mas ao livre jogo da faculdade da imaginação e do conhecimento, cujas produções de sentidos reflexionantes são elaboradas na liberdade que constitui o que de mais próprio há no ser humano.

O princípio intersubjetivo de um sentido comum como fundamento para a multiplicidade de produções e configurações da multiplicidade de produções de sentidos nos interpõe num labirinto sem fim da complexidade dos seus problemas. O mais imediato pode ser talvez a que nos confrange a pensar que, para as sínteses ativo-produtivas do livre jogo de imaginação e entendimento, na produção de imagens e juízos, haja como seu arcabouço absolutamente necessário uma síntese passivo-fundacional de ordem ontológica e transcendente que conceda a todos os sujeitos a comunicabilidade e a presentificação de seus horizontes comuns de compartilhamentos. Isto supõe que todas as consciências estejam em referência ontológica a nível intersubjetivo e interrelação necessária entre si por meio de uma ideia que esteja sendo compartilhada nas suas possíveis variações de sentidos por instanciação que jamais, contudo, a presentifique.

É nesse nó crucial que aflorará sobremaneira a urgência de se pressupor o conceito de razão de ideia estética (de beleza). Kant, pois, procura "traçá-lo":

Uma ideia estética não pode tornar-se um conhecimento porque ela é uma intuição (da faculdade da imaginação), para a qual jamais se pode encontrar adequadamente um conceito. Uma ideia da razão jamais pode tornar-se conhecimento, porque ela contém um conceito (do suprassensível) ao qual uma intuição jamais pode ser convenientemente dada. Ora, eu creio que se possa chamar ideia estética de uma representação inexponível da faculdade da imaginação, a ideia da razão, porém um conceito indemonstrável da razão. (ibidem, p. 204)

A ideia estética de beleza é decorrente da suposição da derivação de gosto do que Kant chamou de "profundamente oculto fundamento comum" (ibidem, p. 74). Impassível de presentificação enquanto tal, e, contudo, fundamento da universalidade a priori do gosto, é o substrato pressuposto também para a aparição fenomênica do belo artístico. Não apenas do belo que como sentimento é 
produzido por reflexão, mas também da obra de arte. Neste ponto, muito facilmente incorreríamos no erro de concebermos o belo como uma propriedade da obra de arte, o que decorreria em contradição. O belo e o sentimento estético não possuem caráter objetivo algum, posto que, por natureza e definição, se mostrem como experiências humanas. Mesmo que estas se relacionem com a obra de arte enquanto um objeto da experiência fenomênica, a subjetividade é a dimensão da origem de ambas. Até porque, de outro modo, a universalidade do belo, repousando na objetividade das obras, seria acessível a todos de forma idêntica - e, com isso, sem abertura alguma para a diversidade infinita de experiências. Desta forma, se o belo fulgura na obra de arte não é porque seja uma propriedade intrínseca ao objeto artístico da representação, mas porque através dele dá-se acesso a uma mais elevada instanciação da ideia estética formalizada em certo ideal que lhe corresponda, ainda que limitadamente.

"Ideia significa propriamente um conceito de razão; e ideal, a representação de um ente individual como adequado à ideia." (ibidem, p. 74) Se a ideia estética não pode ser conhecida de maneira alguma, visto não ser afigurável à sensibilidade, há a possibilidade de que manifestações estéticas singulares se mostrem como the sendo adequadas. Na realidade, podemos dizer que toda obra de arte ou juízo estético propriamente autêntico se manifesta como um ideal - na medida em que, de alguma forma, fenomenaliza a autenticidade da arte como ideia que confere identidade artística à singularidade de um objeto ou juízo estético determinados.

Indemonstrável e infigurável, a ideia enquanto intuição da faculdade da imaginação, entretanto, insinua-se em uma singularidade. Não de forma conceitual ou figurativa, mas talvez como a formalidade de uma origem e destinação suprassensível da arte, que responde pela sua identidade mais intrínseca - e, justo por isso, impossível de ser apreendida em imagem ou compreendida em conceito. Com o termo suprassensível não especulamos nada de metafísico ou divino, em suma, nada que sugira algo de teológico. Longe disso, suprassensível aqui diz respeito ao ontológico reino da liberdade humana, para o qual nenhuma região se apresenta suficientemente adequada para oferecer morada. A não ser estadia. Estadia nas instanciações possíveis de sua insinuação obscurecida, que confere ao fenômeno artístico sua identidade estética e ao mesmo tempo permite uma adequação sintética. Síntese de adequação entre ideia e singularidade, o que faz assomar o ideal como o artístico, porém, sendo essa mesma síntese um lapso que apenas se faz remotamente entrever como uma intuição inexponível - e, portanto, carente de conteúdo, abstrata. 
A condição abstrata, que é criticada por Hegel (1996, p. 76), apresenta-se como o reverso negativo da liberdade humana suprassensível de produção infinita de manifestações estéticas. Hegel critica a estética kantiana pelo seu enraizamento na subjetividade, sem transpor para a realidade tudo o que lograra com as reflexões transcendentais, o que implica com isso que a historicidade da arte fica como uma questão marginal - se é que vem a ser propriamente posta. A crítica ao caráter abstrato das ideias pode ser devolvida a Hegel; afinal, não é a realidade a exteriorização de uma mesma negatividade originária (e, deste modo, abstrata)? Bom, seríamos digressivos se nos enveredássemos por aí. Em todo caso, um comentário de Hegel é deveras pertinente:

(...) o reconhecimento de uma irredutível oposição entre o pensamento subjetivo e a realidade objetiva, entre o universal abstrato e o particular sensível do querer, levara Kant à descoberta de que na moral é onde esta oposição assume o caráter mais agudo, e resolveu-a, ou julgou resolvê-la, sobrepondo o espírito prático ao teórico. (ibidem, p.76)

As consequências dessa sobreposição do espírito prático se fará sentir também na Crítica da Faculdade do Juízo, no momento em que Kant, de alguma forma, vincula as ideias estéticas à moralidade.

A expressão visível de ideias morais, que dominam internamente o homem, na verdade somente pode ser retirada da experiência; mas tornar por assim dizer visível na expressão corporal (como efeito do interior) a sua ligação a tudo o que nossa razão conecta ao moralmente bom na ideia da suprema conformidade a fins (...) requer ideias puras da razão e grande poder da faculdade da imaginação reunidos naquele que quer apenas ajuizá-las, e muito mais ainda naquele que quer apresentá-las. (KANT, 2012, p. 78-79)

Com a subordinação da estética à moralidade, que não deixa de encontrar repercussão no pensamento de Schiller (2013), Kant poderá esboçar algum 
plano mais ou menos sistemático de princípios normativos para a adequação do fenômeno estético à ideia estética. Não constitui nosso interesse entrar no mérito da questão, mas ao menos um esclarecimento nos é exigido fazer. No fundo, essa normatividade presente nas reflexões estéticas kantianas, que não pode ser atribuída somente às compreensões estéticas de sua época, funciona de modo similar à necessidade de postulados práticos para a fundamentação do agir moral. Para Kant, a destinação última do homem é a liberdade no e para seu agir em conformidade com o bem moral. A subordinação, pois, da estética à moral é, de certa forma, um prejuízo do fato de Kant ter vinculado a ideia de liberdade com a moralidade. Assim, quando as ideias estéticas são conectadas ao moralmente bom, para a produção de juízos ou objetos estéticos ideais, não faz outra coisa que o mesmo quanto às ações morais: adequá-las ao máximo ao bem moral para que encarnem em si o ideal.

Entretanto, assim como o subterfúgio de assumir postulados teóricos para a fundamentação da normatividade moral da ação não dá conta dos problemas ontológicos de fundo teórico, que ficam sem solução, assim também os problemas ontológicos da estética ficam irresolvidos por essa subordinação moral.

E talvez o fenômeno que deixe isso transparecer com força total seja o sentimento do sublime. Qual o sentimento do belo, também o do sublime tem sua origem na subjetividade e não está contido em nada do que seja natural, embora com a natureza possua vínculo. O sublime é despertado pelo sentimento terrificante no homem diante de uma ocorrência descomunal no reino da natureza, o que faz com que sintamos que nossas faculdades do conhecimento e da imaginação fiquem temporariamente debilitadas. No momento seguinte, porém, suas forças recrudescem ainda mais, e, com isso, sentimos em nós despertar uma consciência da nossa destinação para além do mundo sensível - do destino da nossa razão para o reino do incondicionado e da liberdade (KANT, 2012, p.108-113).

Para Kant, o sentimento do sublime não se relaciona com nenhum objeto que tenha sido produzido por mãos humanas, somente com uma manifestação natural que inspire o sentimento de pavor ou de sagrado, o que exclui, portanto, a obra de arte. Diante do assombro que amiúde sentimos ao contemplarmos uma obra de arte, isso pode parecer estranho, quando não injusto. Mas Kant aqui é consequente com suas reflexões - aliás, mais do que isso, tal direcionamento o levará a pensar mais profundamente a origem da obra de arte.

Segundo Kant, "a sublimidade não está contida em nenhuma coisa da natureza, mas somente em nosso ânimo (...).” (ibidem, p. 113) As definições subsequentes do sublime, entre algumas que esse filósofo apresenta, são: “o 
que apraz imediatamente por sua resistência contra o interesse dos sentidos." (ibidem, p. 117); aquilo cuja "representação determina o ânimo a imaginar a inacessibilidade da natureza como apresentação das ideias." (ibidem, p. 117) Ir de encontro ao interesse dos sentidos cria resistência e aprazibilidade à faculdade da imaginação, na medida em que esta se vê forçada a sintetizar numa imagem o que de ingente a sensibilidade recebe com total estupefação. Disso decorre a ambiguidade de se sentir tanto enfraquecida quanto aumentada. Mas seu empoderamento não é de modo algum uma doação que os sentidos façam à faculdade da imaginação. $O$ fato de ela se sentir ainda mais empoderada advém, antes, do seu próprio poder, mas que só pode ser aumentado quando precisa se sobrepor àquilo que lhe opõe resistência, e que, no entanto, se encontra em seu poder. A natureza faz força (Macht), violência, de resistência à domesticação conceitual do condicionado operada pelo entendimento. Também a faculdade da imaginação encontra-se domesticada enquanto que opera sob as categorias do entendimento, conforme o esquematismo exposto na Crítica da Razão Pura. A violência da natureza, então, age como o despertar da razão humana para sua condição ontológica da síntese a priori do incondicionado - e, por isso mesmo, para a dimensão suprassensível da liberdade. Desse modo, a natureza faz às vezes de um dispositivo de autopotenciação das faculdades da razão e da imaginação.

A disposição de ânimo para o sentimento sublime exige uma receptividade do mesmo para as ideias; pois precisamente na inadequação da natureza às últimas, por conseguinte, só sob a pressuposição das mesmas e do esforço da faculdade da imaginação em tratar a natureza como esquema para as ideias consiste o terrificante para a sensibilidade (...). (ibidem, p. 113-114)

Grifamos a palavra inadequação como a chave para pensar o porquê de uma obra de arte ou juízo estético não se incluírem à experiência do sublime. A conceituação do fenômeno estético como adequação de um ente singular à ideia estética evidencia a necessidade de se conceber a essência do fazer artístico sob o caráter adequacional. Por tudo que expomos anteriormente, afastamos daqui conceber essa adequação como se fora feito em relação a um paradigma a que se subordinasse (embora isso não seja de todo alheio à Crítica da Faculdade do Juízo, dada a sua parcial pretensão normativa). Essa adequação se dá em relação a uma identidade intangível absoluta, de pura negatividade, e que se dá 
apenas de forma fragmentária no ente individual. A adequação é, por natureza, a refração do incondicionado, em cujo desvio a singularidade surge como o fragmento de uma inexponível unidade. A obra de arte é o fenômeno do declínio da identidade e da unidade. E sua adequação é ser exclusão do terceiro excluído e instaurar-se como simultaneamente ser adequação inadequada em relação a sua diferença identitária. Assim também o juízo estético.

A inadequação, por sua vez, é uma forma de se angariar na subjetividade o inapresentável por meio de uma intuição sobrelevante, que nos constrange a assombrosamente assomá-lo. A receptividade da natureza na experiência do sublime estraçalha as categorizações ordinárias do entendimento (na sua atuação modulatória de determinação do mundo objetivo). Com isso, o que é acolhido pela sensibilidade incide uma força descomunal sobre a faculdade da imaginação, que, uma vez livre dos grilhões das categorias do entendimento, sofre o impacto dessa força e a absorve, potencializando sua capacidade imaginativa para superar os limites epistemológicos da esfera da objetividade e, assim, intuir a natureza como força de oposição correlata, que lhe serve como esquema para as ideias. É claro que a faculdade da imaginação nem assim consegue tornar as ideias presentes. Por natureza, sua conversão em imagem requereria de nós transcendermos as limitações de nossa finitude espaço-temporal. A experiência do sublime atinge-nos, destarte, como um vislumbre muito remoto de sua aparição. A condição do esquematismo na experiência do sublime é que a natureza seja a correlação precisa para a experiência do sublime. Afirmamos isso, aliás, em sentido fenomenológico. A experiência da natureza, territorializando o numênico sob o signo do selvagem, é o correlato "objetivo" do sentimento do sublime como seu ato noético-fundacional de sentido. Deixando à parte o husserlianismo dessa linguagem, também poderíamos dizer, nos inspirando em Artaud: a natureza é o duplo do sublime. Ambos existem em total copertença e reciprocidade, sob a forma geral da relação de sujeito-objeto, mas na extraordinariedade de sua insubmissão a categorias ou estruturas. Ambos são a dupla face de um mesmo movimento de autoaparição da liberdade suprassensível cuja identidade totalitária é intuída como ideia.

Este esforço e sentimento da inacessibilidade da ideia à faculdade da imaginação são eles mesmos uma apresentação da conformidade a fins subjetiva de nosso ânimo no uso da faculdade da imaginação para sua destinação suprassensível e obrigam-nos a pensar subjetivamente a 
própria natureza em sua totalidade como apresentação de algo suprassensível, sem poder realizar objetivamente essa apresentação. (ibidem, p. 118)

A forma de conformidade a fins objetiva foi a definição que Kant deu ao fenômeno do belo, isto é, do aparecimento artístico. Isto, como dissemos acima mais detalhadamente, valia para a obra de arte e para o juízo estético. Mas aqui Kant fala de uma conformidade a fins subjetiva do nosso sentimento em relação à destinação suprassensível da liberdade, o que é assinalado pelo conceito de razão do incondicionado estético, a ideia. Não há a possibilidade de que se realize historicamente essa adequação. Por isso, será sempre o sentimento do sublime o despertar de uma tensão, que não permitirá de maneira alguma uma conciliação.

Pois a faculdade da imaginação (...) quando opera segundo princípios do esquematismo do juízo (consequentemente enquanto subordinada à liberdade), é instrumento da razão e de suas ideias, como tal, porém, é um poder de (...) pôr o absolutamente grande em sua própria destinação (isto é, do sujeito). Esta reflexão da faculdade do juízo estética para elevar-se à adequação à razão (embora sem um conceito determinado da mesma) representa contudo o objeto como subjetivamente conforme a fins, mesmo através da inadequação objetiva da faculdade da imaginação e, sua máxima ampliação em relação à razão (enquanto faculdade das ideias). (ibidem, p. 119-120)

A reflexão a respeito do belo desembocava na forma da conformidade a fins objetiva e na validade comum como condições necessárias para a universalidade do gosto. $\mathrm{O}$ fundamento que lhe era necessário, segundo demonstramos acima, era a comunicação transcendental intersubjetiva. Mas para esta faltava justamente o fundamento da mediação que ela mesma operava. A conformidade a fins subjetiva, por sua vez, exige que retomemos aqui essa carência. Não há para a conformidade a fins subjetiva uma validade comum. A experiência do sublime não é uma experiência válida universalmente, ela sequer parece ser propriamente comunicável. $\mathrm{O}$ empoderamento da faculdade da imaginação em vista de se adequar à destinação suprassensível da razão vê seus esforços 
baldados, em última instância. A inadequação final é seu resultado, posto faltar-nos conceito e possibilidade de, com a imaginação, figurarmos para além do figurável. Mas a imaginação entregue a liberdade pode entrever o que na conformidade a fins subjetiva, isto é, na experiência do sublime, está em jogo. Não o jogo livre da imaginação e entendimento, como no caso do belo. Mas o jogo entre imaginação e razão, no âmbito da liberdade. A tensão entre ambas, no percalço sem fim de alcançar a ideia enquanto o incondicionado, para o qual aponta a experiência do sublime, faz-nos tomar a natureza como esquema para a apresentação do suprassensível, o que, no fundo, não faz senão com que despertemos para o sentido da nossa própria liberdade. A experiência do sublime é, formalmente, uma experiência da nossa própria liberdade. A conformidade a fins subjetiva é precisamente essa experiência, ainda que a natureza nos forneça a matéria para que nossas faculdades trabalhem.

Devida a essas razões, não será fortuito que Kant explicará também a genialidade, como originário da obra de arte, pela experiência do sublime. O gênio é um acontecimento da natureza, que parece possuir um dom singularíssimo e que o distingue abissalmente de todos os demais homens. Contudo, essa natureza não lhe é exterior, mas também não lhe é imanente. A sua genialidade, em parte, advém da sua subjetividade apresentar maior conformidade à tensão entre imaginação e razão. Mas o fundamento e o sentido radical dessa genialidade encontram-se na liberdade humana para a manifestação da multiplicidade infinita da arte, cuja identidade é negativamente intuída como ideia estética.

(...) podemos explicar o gênio também pela faculdade das ideias estéticas, com o que é indicada a razão pela qual em produtos do gênio a natureza (do sujeito) $e$ não um fim refletido dá a regra (à produção do belo). Pois, visto que o belo não tem de ser ajuizado segundo conceitos, mas segundo a disposição, conformemente a fins, da faculdade da imaginação à concordância com a faculdade dos conceitos em geral: assim, a regra e prescrição não podem servir de padrão da medida subjetiva àquela conformidade a fins estética porém incondicionada na arte bela, que legitimamente deve reivindicar ter de aprazer a qualquer um, mas somente o pode aquilo que no sujeito é simples natureza e não pode ser captado sob regras ou conceitos, isto é, o substrato suprassensivel de todas as suas faculdades 
(o qual nenhum entendimento alcança), consequentemente, aquilo em referência ao qual o fim último dado pelo inteligível à nossa natureza é tornar concordantes todas as nossas faculdades do conhecimento. Somente assim é também possível que um princípio subjetivo e contudo universalmente válido encontre-se como fundamento dessa conformidade a fins, à qual não se pode prescrever nenhum princípio objetivo. (ibidem, p. 206).

A genialidade é a mediação fundamental entre a ideia e a singularidade artística. Ele é quem dá forma à sua conformidade pela conformidade a fins subjetiva entre um e outro e, assim, faz surgir o belo como essa comunicabilidade, como fundamento da conformidade a fins objetiva. A validade comum advém do fato de o artista ter sido esse veículo de comunicação. Por meio dele, a ideia (a aparição da arte) comunica-se, não obstante seja em si mesma incomunicável. E a comunicacionalidade advém da própria presença da liberdade na obra de arte: esta é a presença interdita e fragmentária na presente singularidade.

O artista, pois, é aquele cujo espírito é o aberto para a adveniência sublime da supradimensão da ideia beleza na obra de arte. A obra de arte, então, justamente por isso nunca possa despertar o sentimento descomunal do sublime - uma vez que este sentimento propriamente só corresponderia a um sentimento epifânico de uma ideia, o que, no entanto, é despertado em acontecimentos descomunais da natureza. O belo é, então, a compreensibilidade fragmentária da arte e sua manifestação intraduzível por regras ou conceitos. Para sua gênese não há causalidade e nem motivação para sua originariedade. Seu originário é um suprassensível não só para além da sensibilidade como também cognoscibilidade. E contudo vem a ser de forma extraordinária embora escamoteada nas adequações formais para despertar uma contemplativa agradabilidade. Deste acontecimento em que o sublime porém se instaura em limítrofes da sensibilidade, perdendo assim o vigor originário de sua sublimidade, advém o impacto nos expectadores e sua produção contínua de reflexões e gostos. Estes já não são mais passivos diante da obra de arte, mas ativos, na medida em que a própria experiência artística só lhes é destinada de forma produtiva por eles próprios - e para a qual não há regras ou preceitos, mas uso livre de suas faculdades. O que vale para os expectadores também vale para o gênio: não mais se encontram sob o fardo da vigência da mímesis ou da mera imitação. $\mathrm{O}$ caráter representacional da obra de arte passa a ser meramente secundário e até inessencial: seu vigor originário se encontra na transcendência de uma ideia indescortinável em si mesma, mas com 
tamanha pujança que coage a genialidade a alçar voo para além das categorias do mundo objetivo e dar forma em uma singularidade ideal um pálido reflexo da beleza, capaz de criar tamanho impacto nos receptores que os levem a multiplicar sentidos e significações até então inauditos e absolutamente imprevisíveis para a conjuntura atual e as dimensões de determinação de seu mundo objetivo.

\section{Fragmentações extemporâneas de uma simultaneidade}

$\mathrm{Na}$ falta de preceitos, regras, códigos e até mesmo linguagem, para demonstrar a necessidade de uma ideia "subjacente" como fundamento para a arte em sua infinita multiplicidade, é preciso realmente supô-la? Se bem que faça o papel de uma indicação de identidade pela qual toda obra de arte possa ser assinalada como arte, não poderíamos nos contentar, ao invés, com uma força mais múltipla e mais caótica? Não teria Kant aventado harmonia, identidade e unicidade justamente onde mais careça disso? Por ideia dá-se entender uma estaticidade transcendental que semelha demasiado estéril para se pensar propriamente a arte em sua vivacidade. $\mathrm{O}$ vigor pungente de sua historicidade $\mathrm{e}$ temporalidade tampouco são nela divisados. No lugar de arte, tem-se a impressão de falar de uma "artisticidade" - e nesse sentido apriorizar demais e pretender derivar transcendentalmente aquilo que seja mais da ordem de um acontecimento vital imediato. Em suma, não consistiria isso em transcendentalizar demasiadamente a arte - pertencente a um mundo da vida, impassível de ser transcendentalizado?

A ideia como "artisticidade" da arte soa deveras artificial - e talvez artificioso. O próprio Kant, em parte, confessa o embaraço de assumir algo que indique mais ou menos esse sentido como postulado, entre outros pontos igualmente dificultosos:

Esta norma indeterminada de um sentido comum é efetivamente pressuposta por nós, o que prova nossa presunção de proferir juízos de gosto. Se de fato existe um tal sentido comum como princípio constitutivo da possibilidade da experiência, ou se um princípio constitutivo da possibilidade da experiência, ou se um princípio ainda superior da razão no-lo torne somente um princípio regulativo, antes de tudo para produzir em nós um 
sentido comum para fins superiores (...) aqui não queremos, e não podemos, ainda investigar isso; por ora, cabe-nos somente decompor a faculdade do gosto em seus elementos e uni-la finalmente na ideia de um sentido comum. (ibidem, p. 83)

Um princípio superior da razão que sirva de princípio regulativo para um sentido comum é, em instância final, a ideia. Disso, todavia, Kant confessa descurar a fim de prosseguir nas suas investigações que estabeleçam apoio seguro para traçar uma analítica sólida do juízo de gosto. As investigações mais fundamentais exigiriam um aprofundamento ontológico em questões que se encontram para além das expectativas dialéticas da razão.

Mas o sentido comum nos dispõe ontologicamente, mesmo que em meio à plurivocidade e à polissemia de sentidos e significações, para uma comunicação e comunhão que, se não remetem para uma unidade determinável, ao menos indicam um horizonte no qual alguma unicidade pode ser lobrigada. Fragmentariedade e unicidade talvez sejam verso e reverso de uma força originária. Querer derivar aquela desta, como elemento determinante de fundação, pode ser tão forçado e arbitrário quanto o contrário.

Ora, aqui se trata de ver que no juízo de gosto nada é postulado (postuliert), a não ser uma voz universal com vistas à complacência; por conseguinte, a possibilidade de um juízo estético, que, ao mesmo tempo, possa ser considerado válido para qualquer um. (...) A voz universal é somente uma ideia (em que ela se baseia não será investigado aqui. Que aquele que crê proferir um juízo de gosto de fato julgue conforme a essa ideia, pode ser incerto; mas que ele, contudo, o refira a ela, consequentemente que ela deva ser um juízo de gosto, anuncia-o através da expressão "beleza". (ibidem, p. 53)

O sentido comum parece auscultar uma ideia ao mesmo tempo em que reverbera todo um vozerio de diferenças e dissonâncias. Uma voz universal the subjaz como ideia, ideia de beleza. A partir dela os juízos de gosto retiram sua regra, regula, medida. Medida de possibilidade para uma universalidade por meio de uma identidade fundacional que se esconde em cada singularidade 
de juízo. Esta medida, como forma de conformidade a fins objetiva, supõe a subjetiva como o fundamento de mediação pelo qual essa ideia se pode vozear nas obras de arte ou em ajuizamentos estéticos. A referencialidade de auscutá-la consiste nisso. Em toda criação de obras de arte e produção de juízos ecoa um vigor que se expressa como beleza. Por beleza não devemos considerar algo como uma propriedade harmônica ou simétrica, pois do contrário recairíamos em conceitos transcendentes e metafísicos que pretendessem falar das propriedades de objetos como se pudéssemos acessá-los como são em si mesmos. Mas, embora o sentimento do belo seja despertado no sujeito, ainda assim seu sentido último não se arraiga na subjetividade. A ideia da beleza extravasa pela comunhão e pelo compartilhamento do sentido comum os limites da subjetividade e instaura uma partilha transcendental e intersubjetiva cujo sentido último aponta para uma espécie de transcendência.

Evidentemente, com isso ultrapassaríamos as circunscrições por onde o pensamento kantiano tramita, o qual procura se ater a elas como marco e horizonte que lhe concede sustento e legitimidade. Contudo, Kant não se furta de indicar a presença discreta do indizível. Sim, porque sua presença não é nada de fortuito. Ela se faz necessária. E mais do que isso: é a vocação da razão humana postulá-la, mesmo que na sua indemonstrabilidade. É vocação da imaginação sentir-se potencializada a figurá-la, mesmo que não lhe seja possível. Porque, no fundo, também elas duas, a imaginação e a razão, são a presença do indizível na natureza humana. A impossibilidade de apreendê-la ou representá-la nada mais é do que a possibilitação de que o fenômeno humano seja infinito em suas possibilidades. Essa presença é o fundamento da nossa liberdade e da nossa disposição para a originalidade. Nós somos a cada instante essa eterna impossibilidade.

Com o sublime, a experiência dessa presença transpõe a barreira racional da mera possibilidade de sua postulação teórica (como incondicionado fundamento para as condições e condicionados) e traz à tona a fenomenalização do seu sentido. Sentido que se configura sob o signo da natureza e liberdade. Sob o signo do que se apresenta como o totalmente outro selvático e caótico, mas que simultaneamente potencializa e nos desperta para o significado da nossa própria liberdade. Para o sentimento da nossa destinação suprassensível, cujo sentido consiste em nossa transcendência no vigorar da liberdade. Não enquanto uma transcendência metafísica, atemporal. E sim para cumprirmos em nós mesmos esse destino: transcendermos o condicionado com o poder da liberdade, para fazer do mundo a possibilidade de sua efetividade com e na originalidade. Por isso a genialidade é requisito para tanto: ela é a abertura para essa possibilidade enquanto arte. A experiência do sublime é a deflexão da manifestação da na- 
tureza grotesca e alheia para a possibilidade de ser mediação para criação da liberdade. Em outras palavras, gênio é quem consegue trazer de volta para si essa experiência, fazê-la emergir não a partir do dispositivo de resistência fornecido pela natureza, como um acontecimento que lhe é estranho, mas a partir do poder de sua subjetividade, como poder para a liberdade e, portanto, para a criação. De fato, ainda se tratará de um acontecimento, de um acontecimento inexplicável. Mas deste ele não será mais mero espectador. Como criador, seu poder incorporará a força de resistência que se lhe opõe e fará com que o polo de sua subjetividade se torne a mediação pela qual a liberdade venha ao mundo.

Essa força será o quantum de violência ontológica da liberdade que a faculdade da imaginação absorve e que a potencializa para a criação. A receptividade da imaginação é revertida, por essa absorção, em atividade espaço-temporal da pluralidade na unidade, fazendo com que o múltiplo adquira uma singularidade e com que a unidade se fragmente nesta. O espaço da imaginação (Einbildung) abre-se, pelo movimento da intuição para além do imaginável como a unicidade do incondicionado, para ser o campo de construção que sintetiza o múltiplo da unidade em uma singularidade. Da ideia como pura intuição inexponível para a exposição de uma obra da liberdade. Sua temporalidade, por sua vez, consistirá na mediação entre o instante presente e a possibilidade de sua superação temporal, isto é, para além do que é ditado pelas compossibilidades dadas na forma de fluxo relativa ao mundo objetivo (KANT, 2012, p.106). A temporalidade da obra de arte, enquanto essa superação do tempo cronológico para o advento da liberdade é a simultaneidade da obra com a arte, do ideal com a ideia. Com isso, vem a ser a possibilitação temporal do espaço se tornar possibilidade de síntese entre fenômeno de criação e liberdade, dando cumprimento à vocação da razão de realizar no mundo a liberdade. $\mathrm{O}$ tempo da arte é o da ruptura cronológica com o momento, absorvendo sua força temporal para ser oportunidade propícia ( $k a i$ rós) para o exercício da liberdade, mas convertendo essa mesma força em um instante eterno (aión) da obra, em cuja temporalidade o transtemporal da arte se insinua como a era ou geração a partir da qual a obra surge e que, no entanto, a própria obra simultaneamente faz surgir. Nenhuma era se faz sem um instante, da mesma forma que nenhum instante pode se encontrar fora de uma era.

Desta forma, a imaginação é a faculdade dessa mediação. E, por conseguinte, a genialidade se caracterizará como um poder gerativo-imaginativo sem limites. Ela é a temporalização da síntese entre liberdade e criação, realizando no mundo da vida a obra de arte em conformação com a essência da arte, que é inaudita. Inaudita, mas que sopra como voz universal como condição de vozeamento do sentido comum na multiplicidade de vozes distintas e únicas. Irredu- 
tivelmente únicas, mas oriundas dessa mesma tessitura de referencialidade que instaura a possibilidade de sua comunicabilidade e a identidade através da qual são audíveis. A interdição da voz originária é a possibilidade dessa interdicção da Menschheit, da Humanität poder saltar sobre o abismo da incomunicabilidade de sua liberdade em si mesma, ao fragmentá-la para si numa variedade infinita de formas artísticas, gostos, experiências estéticas e reflexões críticas. Ela constitui a esfera da intersubjetividade da experiência estética, sendo o sentido comum seu meio ambiente. Só que muito mais do que pensar esse meio ambiente segundo determinações espaciais, devemos pensá-lo segundo a mediação temporal que ele instala.

Seja como for, a "simultaneidade" convém ao ser da obra de arte. (...) A "simultaneidade", ao contrário, significa aqui que algo de individual, por mais remota que seja sua origem, na sua representação, alcança sua plena atualidade. A simultaneidade não é, pois, uma forma de acontecimento na consciência, mas uma tarefa para a consciência e um desempenho que será exigido dela. É constituída de maneiras a se prender de tal forma à coisa em causa que esta se torna "simultânea", o que significa, porém, que toda intermediação é subsumida em total atualidade. (GADAMER, 1999, p. 210)

A simultaneidade é, portanto, o traço característico da temporalidade do fenômeno estético. A origem remota desaparece na atualidade da singularidade, conferindo-lhe a possibilidade de ser plena, original e única. Nada obstante, como fragmento dessa presença que é ao mesmo tempo ausência. Não se trata de apenas ser essa ocorrência uma forma imanente da consciência - em termos kantianos, uma faculdade. $\mathrm{O}$ fato de ser uma tarefa para a consciência sugere o caráter transcendente de consistir fundamentalmente em doação de sentido, mas que concomitantemente faz exigência de desempenho da subjetividade em lhe corresponder para dar atualidade na plurivocidade de fenômenos a voz desse mesmo sentido. Fragmentariamente, é verdade. Mas precisamente devido a esse caráter fragmentário é que a intermediação pode ser subsumida para dar espaço à plenitude da singularidade na atualidade. A simultaneidade é a parusia no tempo presente entre a atualidade fragmentária do presente e a ausência da totalidade do incondicionado. 
A contemplação visionária da ideia de beleza é-nos vedada, mas uma voz universal em todo nosso vozerio se faz ouvir e nos insinua sua presença nos fenômenos artísticos. Contudo, não há o "sobre-o-que-ela-fala". Não há conteúdos em que se expresse, pois todo conteúdo se encontra já condicionado. O que há então que lhe é próprio? A determinação de beleza é no fundo a mais indeterminada. Ideia de beleza sinaliza para um redobro de mistério fenomênico através do qual um mundo de objetos (a saber, as obras de arte) pode vir a ser e se instalar no mundo e por meio das quais esse mundo pode se sobrelevar à liberdade incondicional do homem.

O acontecimento capaz de apropriar faculdades cognitivas para este fim e igualmente interconectar sujeitos simultânea e historicamente em uma intersubjetividade nos escapa. Sentido comum e ideia são ato e correlato de um mesmo mistério de fundação de mundo e humanidade em recíproca pertença. Por isso toda tentativa e intenção de transcender os limites históricos e transcendentais para se alcançá-los numenicamente estão fadadas ao fracasso. Mas a grandeza metafísica desse fracasso redunda para nós em preciosas narrativas cosmogônicas que nos possibilitam pensá-los e repensá-los, inenarrando sua indizibilidade em formas infinitas ao longo da história.

A narrativa infinita do indizível - tarefa infinita da liberdade estética que é própria da humanidade - supõe auscultar uma voz universal que, contudo, não se anuncia e cuja reverberação sempre decai na originalidade de uma dissonância única e irredutível. $\mathrm{O}$ eco é a cada vez diferente da voz originária, mas em inauguração de sua própria diferença.

O compartilhamento disso cria, no entanto, uma história. A história da arte no Ocidente - ou em qualquer história da arte - segue o continuum temporal cujo liame de prossecução remonta a um Urbild, um modelo original, que se impõe para a tradição como um paradigma a ser replicado (de forma mimética e impropriamente artística) ou transformado ou transfigurado. Essa imposição (com seu pôr-se em movimento de negação e reafirmação) é, na verdade, a responsável pela historicidade da arte para que seu destino prevaleça em meio ao perigo do devir caótico da fragmentariedade e da impossibilidade de paradigmas. Pelo sucesso disso, não propriamente como ideia, mas como modelo, regra ou paradigma é que a beleza passou a ser concebida como uma propriedade do objeto artístico - e daí decaiu em sinonímia com a artificiosa harmonia ou simetria objetiva.

A arte contemporânea, em geral, se apresenta como a contínua demolição - para além dos paradigmas - da Urbild, na esteira dos movimentos de van- 
guarda. Com isso decorre também em descontruir sem cessar sua historicidade. A arte contemporânea é a narrativa da fragmentariedade e a fragmentariedade da narrativa. Os modelos foram destruídos e somente a singularidade responde pela originalidade.

O tempo da narrativa contemporânea já não é mais de progresso, evolução ou desfragmentação. É o da fragmentação e da simultaneidade. O diacrônico cedeu lugar à espacialidade sincrônica. E, no entanto, também nisso converge com a Critica da Faculdade do Juízo. O tempo do mundo objetivo é que apresenta uma forma de fluxo, radicado no sentido primário de condição a priori do sentido interno (do sujeito). Mas a temporalidade do sentido comum e da ideia da beleza não é deste mundo (objetivo), mas pertencem à simultaneidade da intersubjetividade, mesmo quando os sujeitos em um mesmo tempo estejam engajados em recuperar sentidos e modelos da tradição. Não há aqui linearidade propriamente, a não ser quando os próprios sujeitos estão empenhados faticamente nisso. Contudo, mesmo assim, ontologicamente vigora sua simultaneidade, nem que seja "apenas" como condição de possibilidade de surgir o inaudito nesse mundo, tarefa principalmente daqueles que consigo deixam-se criar obras de arte. Não há cronologia para a narrativa da ideia: uma narrativa fragmentária diz tanto (ou tão pouco) quanto uma que force a si mesma uma historicidade.

A multiplicidade infinita de suas possíveis manifestações, impossível de se tornar representável (ou até fora, conquanto num mosaico supratemporal), só deixa ser perfilada sua identidade unitária como a condição de ser a própria ideia estética de beleza de cada obra de arte ou juízo, cada uma como seu fragmento. Sua temporalidade é a simultaneidade de ser o lapso intuível de totalidade que se eclipsa em cada singularidade que ela mesma é enquanto sua condição fragmentária.

A temporalidade fundada na concepção de ideia de beleza, em sentido kantiano, mostra-se talvez tão contemporânea quanto uma que fale de um eterno retorno de vontade de potência. Se nessa se privilegia a impossibilidade de fazer senão a diferença eclodir, a primeira deixa bem claro que uma unidade é impossível de ser alcançada. Ambas em sua fragmentariedade são tecidas e se encontram emaranhadas pelos intercursos de um complexo de uma mesma tessitura, cuja totalidade e eternidade inconsútil não podem jamais sequer serem entrevistas. 


\section{Considerações Finais}

Não pretendemos aqui, como tentamos deixar claro ao longo do texto, esboçar nenhuma visão global a respeito do fenômeno artístico. Há tantas obras quantas suas possibilidades de manifestação - e nenhuma teoria será capaz de abarcá-las. O exercício teórico-crítico encontra suas limitações seja pelo fato de estar condicionado pelo panorama histórico a partir do qual se deriva sua reflexão, quanto pelo fato de que não há possibilidade temporal de se deslumbrar com epifania alguma a arte em sua "essência".

Como vimos, o mundo objetivo carecia de "fundamentação teórica última" que reunisse a multiplicidade das manifestações e instâncias sob um mesmo princípio que as abarcasse pela globalidade de sua unidade, isto é, sob o incondicionado absoluto. Se o alcance da ideia fora uma tarefa infinita, ao menos as suas radicais resistência (aos esforços da razão) e necessidade (ao postulado de uma fundamentação legítima) subsistentes indicavam a universalidade do seu caráter apodíctico, ainda que sob a condição de uma requisição enquanto postulado da razão. A natura naturans numênica das coisas, embora não permitisse seu desvelamento sob a consignação de positividade alguma, efetiva ou virtual, pelo menos deixa seu rastro no negativo das ideias, em relação ao qual o devir fenomênico segue em percalço, mas sem jamais alcançá-lo, posto que seja sua própria sombra - sombra, todavia, em que se põe o sol de sua verdade.

A palavra ideia remonta por demais a uma inteligibilidade visionária do real. Neste sentido, talvez, ela seja propriamente criticável sob o ponto de vista da ininteligibilidade que ela no fundo quer apontar no pensamento kantiano. Contudo, ater-se a uma crítica incisiva à palavra, olvidando sua ressignificação no contexto do pensamento de Kant, seria por demais raso e insuficiente filosoficamente.

Kant, sem sombra de dúvida, é um pensador do seu tempo. E é evidente que sua obra encontra profundas ligações com o espírito da época, com seus pressupostos e vocabulário próprios. Em suma, com a tradição com a qual dialoga de forma direta ou não. Mas como grande pensador extravasa os limites temporais de sua historicidade e se impõe para a posteridade como um campo fértil de reflexão sempre a ser cultivado e retomado. Lemos Kant extemporaneamente e, desse modo, tornamo-lo nosso contemporâneo. Não procedemos anacronicamente, nem sequer intentamos atualizar a filosofia estética kantiana. As atualizações soem em divergir da simultaneidade em que repousa a arte. Simultaneidade de serem todas as obras de arte fragmentos originais de uma mesma originariedade, à qual pertence a arte em todos os tempos. 
A própria palavra beleza traz deveras imensos prejuízos para se pensar o que realmente encontra-se ali proposto. Mas ela só em Schiller alcançará maior clareza de conceituação de seu sentido em Kant. "Beleza é um criptograma para liberdade. A formulação de Schiller para isso diz: 'Beleza é a liberdade nos fenômenos'.” (WELSCH, 2014) Isso implica que sua ontologia não pode ser categorizada, conceituada, estabelecida por regras ou preceitos. Originariamente fundada na liberdade, a beleza não deverá ser imposta como paradigma da arte, mas como a vigência da liberdade singular da obra de arte em expressar fenomenicamente o inefável e o infigurável. Beleza, então, deve ser compreendida como a destinação da obra de arte em manifestar ontológica e poeticamente a arte em uma singularidade irredutível.

Com isso, o pensamento kantiano mostra-se aberto a acolher - ou melhor, a ser acolhido - proficuamente a crítica e a reflexões contemporâneas. Não apenas pela retomada esparsa de um ou outro conceito de forma assistemática e deslocada, a fim de ser atualizado. Mas também como uma forma de pensar mais profunda e organicamente a arte a partir dos baluartes do seu sistema pelo menos em seu metabolismo vital e não em seus elementos secundários. Ainda que, contudo, tal sistema esteja destinado a ser mera compreensão fragmentária e narrativa de um poder que, mesmo nos movendo para a sua correspondência criativamente infidedigna, nos transcende em seu sentido.

Recebido em: 16.05.2014 | Aprovado em: 28.05.2014

\section{Referência Bibliográfica}

ARTAUD, Antonin. O teatro e seu duplo. São Paulo: Martins Fontes, 2006.

HEGEL, G. W. F. Curso de estética: o belo na arte.

São Paulo: Martins Fontes, 1996.

HEIDEGGER, Martin. Introdução à metafísica. Rio de Janeiro: Forense Universitária, 2012.

HUSSERL, Edmund. A crise da humanidade europeia e a filosofia. Porto Alegre: EDIPUCRS, 2002.

.Meditações Cartesianas. São Paulo: Madras,
KANT, Immanuel. Crítica da Faculdade do Juízo; trad. de Valério Rohden e Antônio Marques. Rio de Janeiro: Forense Universitária, 2012.

Crítica da Razão Pura; trad. Manuela Pinto dos Santos e Alexandre Fradique Morujão. Lisboa: Fundação Calouste-Gulbenkian, 2001.

NIETZSCHE, Friedrich. Vontade de potência. Petrópolis: Vozes, 2011.

SCHILLER, Friedrich. A educação estética do homem. São Paulo: Iluminuras, 2013. 
WELSCH, Wolfgang. Schiller revisited: "Beauty is freedom in appearance" - Aesthetics as challenge to the modern way of thinking. Contemporary aesthetics. Castine: vol. 12, jan. 2014. Acesso: http://www.contempaesthetics.org/newvolume/pages/article.php?articleID $=694$. Acessado em: 18 de junho de 2014.

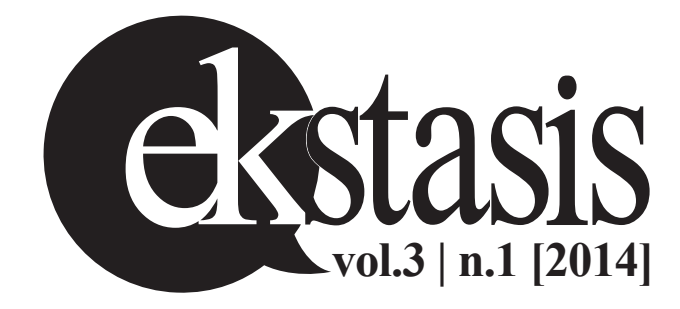

